\title{
New challenges for mentoring based on international references. A brief comparative study
}

\section{Nuevos desafíos para la tutoría basados en referentes internacionales. Un breve estudio comparado}

\author{
REYES-MONJARAS, María Elena*† \& REJÓN-JIMÉNEZ, Ysela \\ University of Carmen \\ University of Salamanca, Spain
}

ID $1^{\text {st }}$ Author: María Elena, Reyes-Monjaras / ORC ID: 0000-0001-9335-2352, Researcher ID Thomson: G-2056-2018, arXiv ID: Maria_Elena_Reyes, CVU CONACYT ID: 90119

ID $1^{\text {st }}$ Coauthor: Ysela, Rejón-Jiménez / ORC ID: 0000-0002-7829-5457, Researcher ID Thomson: G-2089-2018, arXiv ID: ysela60, CVU CONACYT ID: 900052

\begin{abstract}
New Challenges for Mentoring Based on International Standards is a comparative study that shows a qualitative analysis conducted by a group of researchers from the Autonomous University of Carmen, Mexico, based on the figure of mentoring, as an essential element in institutions of higher education superior in this country, whose approach is aimed at the conceptualization, development and application of tutoring from the educational perspective and from the results obtained in the comparative analysis with the University of Salamanca, Spain, in order to observe the behavior and impact at the European level, to identify successes and areas of opportunity with respect to said institution.
\end{abstract}

Challenges, Tutoring, Study compared

\begin{abstract}
Resumen
Nuevos desafios para la tutoría basados en estándares internacionales es un estudio comparado que muestra un análisis cualitativo realizado por un grupo de investigadores de la Universidad Autónoma del Carmen, México, basado en la figura de la tutoría, como elemento esencial en las instituciones de nivel superior en este país, cuyo enfoque se dirige a la conceptualización, desarrollo y aplicación de la tutoría desde la perspectiva educativa y a partir de los resultados obtenidos en el análisis comparativo con la Universidad de Salamanca, España, con la finalidad de observar el comportamiento e impacto en el ámbito europeo, para identificar aciertos y áreas de oportunidad con respecto a dicha institución.
\end{abstract}

Desafíos, Tutoría, Estudio comparado

Citation: REYES-MONJARAS, María Elena \& REJÓN-JIMÉNEZ, Ysela. New challenges for mentoring based on international references. A brief comparative study. Journal of Systems and Educational Management. 2019, 6-18:14-23

\footnotetext{
* Correspondence to Author (email: m.e.reyesmonjaras@ hotmail.com)

$\dagger$ Researcher contributing first author
} 


\section{Introduction}

This paper emerges from the analysis carried out in educational research from a qualitative perspective, which shows results obtained through interviews, based on the theory grounded as analysis and research methodology.

The study focuses, in particular, on the bachelor's degree in law; however, the main objective is to develop a comparative study not only with various educational programs, but also with two higher education institutions based on forums and applied instruments at the Autonomous University of Carmen, Mexico, during 2017 and 2018; as well as at the Faculty of Education and Law of the University of Salamanca, Spain.

The purpose has been to compare the function and conceptualization of the mentoring figure, regarding the Autonomous University of Carmen, in particular the Faculty of Law, with the purpose of observing the behavior and impact in the European scene, which contributes to identifying achievements and areas of improvement with respect to said institution, providing a great scientific advance in mentoring as key figure in higher education institutions.

As part of the project activities, the first Forum on the Importance of Mentoring in the Various Education Programs of the Autonomous University of Carmen was held in May 2017, as well as the second Student Forum of the Early Training Workshop for Researchers in November 2017; the second Forum on the Importance of Mentoring in the Various Education Programs of the Autonomous University of Carmen in August 2018; and complemented with a research stay, during the period between September and October 2018, in which a series of activities were prepared, such as interviews with professors and administrative officials of the Faculty of Education and the Faculty of Law of the University of Salamanca, Spain, as well as some students of the education program; in addition to the search for updated and relevant sources, related to studies develop by the university itself, which gave structure to the results presented here.

\section{Methodology}

The work is based on a descriptive exploratory approach, of a qualitative nature. The sample population consists of university professors and administrative officials of the Autonomous University of Carmen, Mexico and the University of Salamanca, Spain, belonging to various education programs of the Faculty of Education and the Faculty of Law. The sampling was not probabilistic by criteria, pretending that the sample was qualitatively representative of the reference group, ensuring homogeneity based on characteristics such as academic level, functions, and areas, in order to propose as inclusion criteria that the entire sample would be related to the teaching learning, and mentoring processes as indicators of this project.

The information was collected between September 2017 to October 2018, derived from a research stay held at the University of Salamanca, Spain from September 18 to October 18, 2018; and from various forums held at the Autonomous University of Carmen, Mexico, based on the grounded theory of Strauss, A. and Corbin, J (2002: 354), whose procedure through induction leads us to generate explanations around sociological issues, as is the case with this research, since they analyze two categories, teaching and mentoring, to determine the impact on student training, the scope and limits in mentoring work and the areas of improvement, as well as its challenges. Thus, two strategies were used: a) the constant comparative method and b) the theoretical sampling.

Four fundamental research categories were proposed, from which the procedure was developed:

1. Conceptualization or definition of mentoring at higher education level. Related to the knowledge of figure.

2. Application and development of mentoring in study programs at a higher level. Related to the teacher's attitudes and skills.

3. Scope and limits in the development of mentoring. Related to the challenges and improvements around mentoring. 
The impact of mentoring on university students. Related to the student's attitudes and skills. A series of questions were structured around these categories, the answers of which were analyzed to narrow down the objective of this paper and reach conclusions that could provide ideas in order to achieve improvements.

\section{Discussion}

\section{Mentoring in universities}

It is important to point out some conceptual aspects prior to the explanation of the field work. At an international level, there has been a change in the conception of university teaching, derived from the various evaluation processes. As a result, a series of actions have been generated aimed at improving the attention and monitoring of students in a personalized way, usually from the beginning until the end of their studies, which has served to outline the mentoring action.

The interest in mentoring is born as an attempt to respond to the needs of the university institution and the students who access it, Rodríguez Espinar S. (2012: 10), the orientation and mentoring processes are considered indicators of quality of higher education institutions.

Mentoring is not something new, it can be said that since the dawn of the university institution mentoring has existed, understood as the accompaniment of students in their training or professional career, what really varies are the conceptions or university models.

The mentoring models which are developed at universities, from Anglo-Saxon, Germanic, Latin, Oriental, public or private tradition, range from: the Bureaucratic-official, in which the professors limit themselves to complying with what is established institutionally, i.e., covering the time determined to student attendance, correction and revision of exams; this is the most applied model at Spanish universities; the Academic, which focuses solely on mentoring by the teacher in case studies and academic field work, among other tasks; and the Educational, assumed as a form of teaching in small groups, focused on the good assimilation of ideas, concepts and notions, Rodríguez Espinar, S (2012: 10).
According to Álvarez González, M, et. al (2015: 20), within a holistic training model, it must include the following dimensions of intervention, which contain areas related to the student's personal development, such as the cognitive intellectual dimension, the affectiveemotional dimension, the social dimension and the professional dimension, which vary according to the tradition of each country, sometimes leaning towards a paternalistic relationship, as in the case of Latin American countries which does not necessarily determine the integral development of the student, especially if we refer to promoting independence, responsibility and maturity in the university students, so that they are able to solve problems.

The global transition in the current century forces higher education institutions to propose strategies to overcome gaps and move forward according to the new horizons of education, Romo L. A (2011:21).

Mentoring is an action inherent to the teaching function; in retrospect, we can say that it has been part of its work since the dawn of the university, understood as the accompaniment of students, Rodríguez E. S, Coord., (2012).

It is important to mention the transition from the technological to the knowledge society through the convergence processes initiated in Europe at the end of the 20th century, which have influenced reforms of the Ibero-American pedagogical systems.

Within the advances or transformations in the education field, we can point out the impact of the mentoring function, the purpose of which is to raise the level of educational quality in the various institutions of higher education.

In this sense, the teacher-mentor must rely on the four pillars proposed by UNESCO of the International Commission on Education for the 21 st century, which are: Learn to know, learn to do, learn to work and learn to be, Mogollón D GA (2006: 115). 
Because the global challenge of educational transformation requires training professionals with a humanistic, thoughtful, critical and comprehensive nature, capable of collaborating with the change and dynamics of their environment, the mentoring activity is essential, and it should be conceived as a systematic, intentional, articulated and programmed activity.

It has been considered that mentoring is essential in the process of training university students, although in various institutions it has been used as a remedial measure to avoid dropping out of school and increase terminal efficiency; however, it is not a formula that allows to solve all educational problems, but it does entails benefits for the students if it has an adequate management and development Narro R. J. and Arredondo G. M. (2013: 108).

Mentoring is a task that teachers perform as part of their functions, which implies developing a series of skills, attitudes and abilities that allow the integral development of the student through constant guidance and monitoring. In the case of higher education, it must be throughout several stages: at the beginning, during and at the end of their university course, Reyes Monjaras. M. E. (2018: 108).

It is a fundamental element in the training of university students and so, we have considered that if it is done properly, it allows the promotion of values, stimulates students to avoid dropping out, achieves decrease in failure rates, increases terminal efficiency and generally contributes to the training of professionals capable of dealing with and solving problems in the labor field.

It is an accompaniment that the teachermentor carries out during the student's academic career; it is an attention that is not only focused on the academic aspect, but also on various areas of the student's life, which have an impact on their professional development.

As an intentional event, mentoring must be planned, have specific objectives and be based on the relevant aspects that impact the student's performance.
At present, mentoring is becoming more and more relevant as a university competence; however, the concept of mentoring depends on the meaning of the university and the social approach of scientific discovery, Lázaro Martínez A. (1997: 233). The role of the teacher-mentor focuses on two major educational fields: the intellectual and the affective-maturation. The first encompasses: instructional training, teaching, exigency and scientific teaching; as for the second: socioemotional training, counseling, understanding, and psychopedagogy counseling.

Mentoring has been present at various times, training spaces and educational levels, both national and international, it has been considered to contribute to the integral formation of the students, that is, to their personal, social, emotional, cognitive and academic development Obaya V. A and Vargas $\mathrm{R}$ and M (2014: 479).

Therefore, mentoring should not be considered only from an academic point of view, since it promotes processes of selfknowledge, dialogue, self-regulation, skills development, assertiveness, identification of risk factors, active peer listening and with the mentor, which helps their coexistence and shaping of identity.

It is important to highlight that the mentoring models implemented vary according to the cultures and traditions of the countries; however, they agree on considering mentoring as an indicator of educational quality, taking as a reference the results obtained by students through the evaluation, performance, reduction of risk factors such as failing and dropping out of university studies.

According to the research instruments applied to the project "Proposals to Improve Mentoring at the Autonomous University of Carmen" at a higher level, mentoring is not only focused on academic aspects, as we mentioned previously, since students face many personal, family, psychological and emotional processes which they sometimes cannot solve satisfactorily and transcend their academic performance, impacting on satisfaction fulfillment concerning their professional goals. 
In other words, mentoring is related not only with academic intervention, but also with the approach of dialogue to the students' way of thinking and interests.

In this regard, the work of the mentor is fundamental; however, the difficulty lies in determining the scope and limits of this function, as well as the responsibilities and challenges involved in carrying out that work, even more when the educational advances to national and international level, the educational processes being the main factor of progress of a nation; so, it must be in constant transformation, especially teaching and, as part of it, mentoring, having as important references the European Higher Education Area (EHEA) in relation to university higher education.

That said, based on the reports and considerations presented by the United Nations Educational, Scientific and Cultural Organization (UNESCO), being an organization concerned with universal education and in particular with university education, who remarks the importance of higher education and its relevance in the progress of societies towards their well-being, with emphasis on the generation and transmission of knowledge, but also on their social projection Aguilera G. J. L. (2010: 26), all of which impacts on mentoring as part of teaching. It is also relevant to indicate to what extent there has been a redefinition and institutionalization of the mentoring action in the education system that guarantees quality education.

As stated by Paula García and Mirian Miranda, the mentoring action is a process framed in the educational orientation that complements the teaching action. It is an integral part of the center's processes, a set of collective and coordinated intentions and activities that involves all members of the educational community at all levels of intervention CIMIE (2016).

The effectiveness of the mentoring action at a higher level requires not only a clear regulation or normalization in each educational institution, which allows the identification and application of the limits and scope of said work, from the mentor as well as the student, but the application of public policies that contribute to its realization is also necessary; that is, that they focus on the objectives, purposes and proposed goals.
The analysis of functions from various perspectives, approaches and contexts will also allow adaptation and transformation to current demands.

\section{The international contexts. University of Salamanca, Spain}

The strategic and complex challenges of international mentoring parameters based on the observations and projects of UNESCO, the trend of the technological society towards the knowledge society, involve a series of important elements that allow the process to be built and improved and, of course, mentoring is a fundamental part. Such elements range from the implementation of information technologies, strategies that contribute to the process and assimilation of knowledge, as well as an element to support it such as human rights, going from the right to education, to freedom of expression, the right to take part in cultural life, all of which is reflected in the integral development of the student, which is the final goal.

Mentoring as part of the teachinglearning process at the international level has not only evolved according to quality requirements but has also been included within the normative scope of education in various countries in order to standardize the parameters.

Based on the work carried out within the research project CAIPI/2017/03, Proposals to Improve Mentoring at Unacar, a research stay was conducted at the University of Salamanca, Spain, so it is relevant to indicate the historical background of the institutionalization of the mentoring action in the Spanish education centers, since it is the country where the present study was carried out.

The need for mentoring action and consequently of its organization is recognized and promoted through a legislative development born from the General Education Law of 1970, which considers the mentoring action as the central axis of the educational activity. 
Likewise, for the first time the figure of the mentor and the mentoring action appear in the Spanish educational regulations and hand in hand, a new structure of the education system was proposed in the legislation for all educational levels by recognizing the right to orientation and the mentoring function as an integral element of teaching, with a constant attempt to attribute specific functions to the mentor. It is not until 1990 that the mentoring function is extended and consolidated as an essential part of the curriculum development, the tendency of which is to attain comprehensive and quality education, González A. M. (2014).

The present study was carried out in coordination with Dr. María José Rodríguez Conde, director of the University Institute of Research in Educational Sciences (IUCE). This institute is characterized by its interdisciplinary nature, structural conformation, as well as its research task as teaching center, and from the point of view of research, since it ranges from the application of new technologies to training processes, both the teams and the topics studied, the methodological and didactic aspects, participate in different disciplines depending on the formative content.

This Institute is comprised of several research groups that are described below:

- E-LECTRA. Research group on reading, digital publishing, transfer and evaluation of scientific information. It has been established to study emerging phenomena linked to electronic publishing, digital literacy and metrics related to scientific information.

GE2O. Educational evaluation and guidance group. It focuses on aspects such as skills-based training, evaluation of education programs, training and evaluation processes in virtual environments, educational and professional orientation or educational measurement and evaluation.

GITE-USAL. Research Group Innovation in Educational Technology. It works in the field of educational innovation through digital technologies.

\begin{abstract}
ROBOTICS AND SOCIETY GROUP. The lines of work of this group are: autonomous robots, supervision and industrial control, robotic manipulation, artificial vision, communications, mass computing, robotics in education, training in medicine, food technology, among others IUCE (2018).
\end{abstract}

This institute, according to the information provided by its director USAL (2018), receives an external evaluation conducted by quality agencies, which rate the production generated by the research groups, the number of projects and the joint work, among other indicators, and if the institute complies with the necessary indicators, they certify it as a research Institute for a determined period of time.

Another fundamental element is that all the curricula of public and private universities must cover a series of obligatory sections established in Royal Decree 1393. Among the planning they carry out, they must include support and guidance to students. As it can be seen on the official website, there are services offered by the University of Salamanca to all students of the various educational programs; which are listed as follows:

1. Cultural activities

2. Social affairs

3. Scholarships and study aids

4. Schools, residences and cafeterias

5. Physical education and sports

6. Languages

7. Professional insertion, internships and employment

8. Promotion, information and guidance USAL (2018).

The second item on the list, Social Affairs, is responsible for responding to the information, advice and support needs that the university community may require in order to guarantee equal opportunities and contribute to the improvement of personal and social wellbeing.

It also promotes among university students responsible commitments to society and active participation in the defense and the fight for diversity and human rights in the following fields: 


- $\quad$ Social support
- $\quad$ Support for the university community
with disabilities
- $\quad$ Psychiatric support
- $\quad$ Participation and volunteering
- $\quad$ Development cooperation.

It is in this area where diverse problems are addressed, unrelated to any academic issue, which in the case of the University studied, the mentors are not required to solve, but only to channel that department if necessary.

\section{Analysis of results}

According to the applied research instrument, regarding the first category Conceptualization or definition of mentoring at higher education level. Related to the knowledge of figure, it was asserted that mentoring is part of the students' continuous training and the work of the teacher.

The interviews showed that both the instructors and the officials who perform the functions of teachers agree to bestow importance to the mentoring figure, has an assigned hour load to perform the mentoring, both individual and in group; however, it is a type of academic mentoring, the focus of which leans towards the advice on the courses taught or the direction of thesis.

Furthermore, another type of mentoring is added, that of peers, designating a group of students of more advanced degrees, who are inserted into a volunteer program, in order to follow-up or support students of lower grades and to guide them in regards of the choice of courses and decision making in some respects.

In respect of the second category, Application and development of mentoring in study programs at a higher level. Related to the teacher's attitudes and skills, through the interviews it was stated that the development of the mentoring action in some cases varies according to the course taught and the number of students enrolled in said course.

Even some stated that it is related to the affinity one has with the teacher, since some students do not attend mentoring with a certain teacher, due to lack of affinity, fear, disinterest, among other factors.
Regarding the third category, Scope and limits in the development of mentoring. Related to the challenges and improvements around mentoring, the answers agreed that mentoring is limited exclusively to "academic" issues, such as clarifying doubts, addressing topics of interest, follow-up of research papers, direction or thesis advice, emphasizing on the part of some respondents that in no case are treated, addressed or resolved "personal", "psychological" or "social" problems, nor is there contact with parents, because they are older of age. Nonetheless, others stated that in some exceptional cases students asked for guidance or advice on some issues and the teachers/tutors answered, but they are channeled in the end to the Social Affairs Service of the university, which is responsible for attending non-academic issues.

As for the fourth category of analysis, The impact of mentoring on university students. Related to the student's attitudes and skills, it is concluded that the impact of mentoring on students is reflected in terminal efficiency and in the training of human resources, that is, in the culmination of their training and the corresponding obtention of a degree through the presentation and defense of a thesis, USAL (2018).

In an interview with the dean of the Faculty of Law, Dr. Fernando Carbajo Cascón USAL (2018) said that they have the following educational programs: four degrees, Law, Political Science, Public Administration, Criminology and Global Studies; four double programs degree: Law and Criminology, Law and Political Science, Law and Business Administration, and Political Science and Documentation, with a total of approximately 2600 students. They also have thirteen masters and $\mathrm{PhD}$ students who add approximately 1000 more within their enrollment. $\mathrm{PhD}$ students are not counted within this registration because the courses are not face-to-face; to which can be added the degrees from the university, many related to Law, of which we do not have the data.

Regarding the staff of professors, the faculty has approximately 125 , among them full-time and part-time professors, the latter are categories of associate professors who are normally legal professionals that collaborate with practical classes. 
He also indicates that the professors carry out the following activities: teaching, research (national, regional or international research projects and organization of extraordinary activities, such as congresses, seminars, research days, etc.), some perform management tasks (deanery procedures, department management, administration of the university's own degrees, master's degrees direction and coordination, double degree coordination).

As for mentoring, within the ordinary teaching of degree and master, mentoring is provided, in the academic modality, through the final degree projects, and in the master's degree with the final project and the doctoral theses, being understood as mentoring by the teachers. Within the ordinary mentoring, the days and hours of the mentoring are usually set or are arranged via email, depending on the teacher's work load to answer questions. Another type of mentoring that applies in said faculty is collective mentoring, which takes place a few days before the final exams and one or two classes are held to answer questions.

It is emphasized that in the case of personal or family problems, the university has a social assistance department, in some cases the professor or the dean, in serious cases, refers or channels the student to that department.

The aforementioned is consistent with the model of mentoring followed in the European scene, which is based on the central idea of focusing the teaching-learning process in the student and that the university's orientation and mentoring should serve in this technological and knowledge society as a platform for those who graduate from it, to leave with a more defined personal and professional life project and also acquire the necessary skills to face this project in their life.

Thus, mentoring is inherent in the teaching process, Learning Lobato-Fraile, C. and Guerra Bilvao N, (2014: 23). It is shown in the European context that from 2003 to 2012 mentoring in the teaching-mentor and peer-topeer modalities has grown considerably, which evidences a formative effectiveness, recognizing mentoring as an indicator of educational quality in higher education.
It is more of an accompaniment to the student as an educational practice, which allows to build, elaborate, carry out and evaluate their personal and professional projects, having a space or scope of action that contributes to the formation of maturity, responsibility, commitment and freedom of decision for the students themselves in their training process.

In Mexico, higher education institutions have implemented institutional mentoring programs based on the recommendations of organizations such as the National Association of Universities and Institutions of Higher Education (ANUIES).

The particular case of the Autonomous University of Carmen, where several groups of researchers develop projects related to mentoring, has resulted in academic forums held in 2017 and 2018, UNACAR (2018), where teachers and students of various educational programs have participated by presenting papers on the following topics:

- Teaching experience in mentoring
management
The impact of mentoring on student
development
Academic mentoring as a strategy to
improve educational quality
- Implementation of novel strategies in
mentoring
Social problems and their possible
solutions through mentoring
Progress and impact on mentoring.
Consolidation of the institutional
mentoring program.

In such forums, about 42 teachers and 11 students of educational programs such as Law, English Language, Educational Sciences, Business, Health Sciences, among others, had the opportunity to exchange ideas, experiences and proposals around mentoring, which allowed to detect areas of improvement, especially in terms of the scope and limits in the role of the mentor, which is essential in any higher level institution, since it contributes to the improvement of the education processes and the professional development of students. 
It is important to highlight that in 2017 and 2018, surveys were conducted to 461 students of various educational programs of the Autonomous University of Carmen, as well as approximately 40 interviews with professors of the same institution by the disciplinary group of Law.

This was implemented with the purpose of observing the positions and considerations about mentoring, both from the point of view of the mentor and the student, which gives rise to important considerations for the improvement of mentoring at a higher level.

According to the analysis performed and the comparative generated, it is important to note that in both contexts (Mexico-Spain) there is recognition regarding mentoring as part of the teaching-learning process at all education levels, which develops a mentoring action plan to follow for each school year.

This action is evaluated through indicators of quality, terminal efficiency, decrease of drop-out rates, and problem followup through appropriate channels.

In addition, in most institutions there are regulations which allow to identify the scope and limits of this function; however, the great difference lies in very defined cultural aspects, such as the "emotional" links generated from the tutor-student relationship, since in Mexico it is difficult to separate the strictly academic margin from the personal or affective.

That is why it is important to consider a general reassessment of the mentoring action, its scope and limits, as well as the appropriate actions that allow the student to be guided or directed towards an integral development and not in the solution of their existential problems, since that would exceed its work and hinder the effectiveness of its function at any educational level and therefore the impact on students.

\section{Acknowledgments}

To the Autonomous University of Carmen, which funded the research stay carried out at the University of Salamanca, Spain, through the General Directorate of Research and Postgraduate.

\section{Relevant suggestions}

The mentoring figure is important at all educational levels; however, at a higher level it has been given, at least in Mexico, a paternalistic approach, in the sense of trying to solve all the problems faced by the student in all areas of their life, which is an incorrect approach from our point of view, since at that level students must learn to solve and face their problems on their own, perhaps with a guide or support, but with established limits. We also consider that peer mentoring should be implemented, that is among students, involving them in follow-up programs and support for first-grade students in topics such as choice of courses and areas, decision making, among others, and of course give more importance to academic mentoring, supporting courses and the training of human resources with the direction of bachelor's, master's and doctoral theses, since, at least in the Faculty of Law, there are no high rates of terminal efficiency through the elaboration of theses and their respective presentation and defense before a jury, due to various factors, including lack of motivation on part of the professors.

A change of culture and mentality is required in the conception, organization and application of mentoring by university agents (professors/mentors, administrative staff/managers, and students), that is, a change in perspective. While it is true that the importance attributed to mentoring in relation to the training of university students is correct, the application or operation of it has deviated from its main purpose, i.e., it has exceeded the merely academic aspects, to get involved in aspects of various kinds.

\section{Conclusions}

The present study allowed us to observe a different panorama from the one developed in most Latin American countries regarding mentoring, which tends to a paternalism that hinders the professional development of the student in an effective way.

The analysis of the instruments applied shows a purely academic perspective in the development of mentoring in universities in Europe, which is reflected in the potential that students develop, both individually and professionally. 
Therefore, it is observed that respect for their freedom and autonomy in decision making is part of the training of professionals, which allows them to acquire a greater degree of maturity and to be able to solve problems in their professional areas. It was observed from the normative revision that the lack of clear and specific guidelines regarding mentoring limits the adequate development of the function and causes confusion and doubts on part of the students regarding their rights and obligations.

\section{References}

Álvarez-González, M, Ballerter-Brage, L. y Nadal Cristóbal, A (2015), La tutoría en la universidad. El reto del docente hacia la convergencia europea. Una experiencia en educación social- UIB, en Nuevos desafíos en la educación Tomo II, Salvador Peirò i Gregòri, coord. de la edición, ECU, 2015, Spain, p. 20.

Aguilera, G. J.L. (2010), La tutoría en la universidad: Selección, formación y práctica de los tutores. Ajustes para la UCM desde el espacio europeo para la educación superior, doctoral thesis. Universidad Complutense de Madrid, Spain.

CIMIE, (2016), García M. P y Miranda M. M, Retos de la acción tutorial en el sistema educativo actual, CIMIE 16, Education Research with social impact, Consejería de Educación y Cultura, Sevilla.

González A. M, (2014), Antecedentes y evolución histórica de la acción tutorial: Apuesta por una educación integral y de calidad, CIMIE 14, Tercer Congreso Internacional Multidisciplinar de Investigación Educativa, Segovia, Spain.

IUCE, Universidad de Salamanca, official website, accessed in September 26, 2018, available at: https://iuce.usal.es/

Lázaro Martínez, A. (1997), La acción tutorial de la función docente universitaria, Revista complutense de Madrid, 8 (1), Universidad Complutense de Madrid, Madrid, pp. 233-252.

Lobato-Fraile, C. y Guerra-Bilbao, N, (2014), Las tutorías universitarias en el contexto europeo, Orientación y sociedad, Vol. 14, January-December, Universidad Nacional de la Plata, Faculty of Psychology, Spain, pp. 23
Mogollón D. G A (2006), Éxito del tutor universitario, Revista Ciencias de la Educación, Year 6, Vol. 1, No. 27, Valencia, January-June, pp.109-122.

Narro R. J y Arredondo G. M, (2013), La tutoría, un proceso fundamental en la formación de los estudiantes universitarios, Perfiles educativos, vol. XXXV, No. 141, IISUE-UNAM, Mexico.

Reyes Monjaras M.E, (2018), Reflexiones en torno a la tutoría y su impacto en los estudiantes, Letras Jurídicas, (37), Universidad Veracruzana, January-June, Mexico, 2018, pp. 107-116.

Rodríguez-Espinar, S. Coord. (2012), Manual de tutoría universitaria. Recursos para la acción, Octaedro ICE, Universidad de Barcelona, Spain. pp. 151

Romo L. A, (2011), Tutoría, una estrategia innovadora en el marco de los programas de atención a estudiantes, ANUIES, Mexico.

Obaya V. A y Vargas R.Y.M (2014), La tutoría en la educación superior, Investigación educativa, 25 (4), UNAM, Mexico pp. 478-487.

Strauss, A. y Corbin, J, (2002), Bases de la investigación cualitatitva. Técnicas y procedimientos para desarrollar la teoría fundamentada, Contus, Antioquia University Press, Colombia, pp. 354.

USAL, (2018), Universidad de Salamanca, Spain, available at: http://www.usal.es/servicios-de-asistencia-a-lacomunidad-universitaria

USAL, (2018). Observatorio de la calidad y rendimiento académico. Unidad de evaluación de calidad, accessed in October 2, 2018, available

at: http://indicadores.usal.es/transparencia/estudian tes.html.

USAL, (2018). Universidad de Salamanca, Spain, available at: http://www.usal.es/asuntossociales-sas 